\title{
小川原湖の内部流動と混合現象に関する現地観測 \\ FIELD MEASUREMENT OF WIND-DRIVEN CURRENT AND MIXING IN LAKE OGAWARA
}

\author{
西田修三 ${ }^{1}$ ・佐 野俊 幸 ${ }^{2}$ \\ Shuzo NISHIDA and Toshiyuki SANO \\ ${ }^{1}$ 正会員 工博 大阪大学大学院助教授 工学研究科土木工学専攻（干565-0871 吹田市山田丘 2-1) \\ ${ }^{2}$ 学生会員 大阪大学大学院 工学研究科土木工学専攻 (†565-0871 吹田市山田丘 2-1)
}

\begin{abstract}
Structures of wind-driven currents and water temperatures were measured to clarify the mixing process in a brackish lake with salinity interface at about $20 \mathrm{~m}$ depth. Time series data were collected at every $1 \mathrm{~m}$ depth by using an $\mathrm{ADCP}$ and a thermistor chain.

Current of about $20 \mathrm{~cm} / \mathrm{s}$ was generated by the wind speed of about $10 \mathrm{~m} / \mathrm{s}$, and continued for long time after the wind stopped due to generation of internal waves. Vertical profiles of velocity gradient indicated high values not only in thermocline region but also in the vicinity of the salinity interface. Profiles of gradient Richardson number had small values less than 1.0 in these layers and surface layer. This means that there are possibilities of mixing in some layers, and in fact an increase in the potential energy was detected after wind blew.
\end{abstract}

Key Words: Stratified lake, wind-driven current, Richardson number, mixing, ADCP

\section{1.はじめに}

湖沼では熱的鈆直循環の他に風に起因した大きな 流動や内部波の発生も見られ，湖沼水の混合に大き な役割を果たすことが知られている．しかし，計測 の難しさと現象の複雑さから, 現地スケールでの現 象の把握と混合過程の定量化は未だ十分にはなされ ていない1),2),3).

これまで実施されてきた湖沼の現地観測は，時空 間変動が緩やかで, かつデータの採取が比較的容易 な水温構造をはじめとする水質観測が中心であった. 一方, 流動に関しては, 微流速であるうえに時空間 変動が大きいため, 有意なデータの採取が難しく, 観測例は少ない。

さらに，多様な生態系を有する汽水性湖沼では， 水環境と生態系の保全からその実態把握が必要とさ れながらも, 水温成層と塩分成層が混在し現象を複 雑化しているとともに，現象の普遍性に増して個別 性が強く, 流動と水質を十分な精度で予測するには

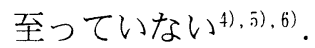

そこで, 本研究では汽水湖である小川原湖をフィ ールドに, 風に起因した流動と混合現象に着目した 現地観測を実施し，その実態の把握と成層破壊機構 について解析を行った．流動の観測には，超音波ド ップラー流速計 (ADCP) を使用し, 水温の多点観測と あわせて, 流動と成層構造の同時計測を実施した.

\section{2. 小川原湖の概要}

観測を実施した小川原湖は, 青森県東部に位置し, 八甲田山系に源を発する一級河川高瀬川水系の一部 をなしている. 約 $6 \mathrm{~km} の$ 高瀬川を介して太平洋に繋が る, 湖面積 $63 \mathrm{~km}^{2}$, 平均水深 $11 \mathrm{~m}$, 最大水深 $25 \mathrm{~m}$ の湖で ある（図-1）。淡水供給は主要 6 河川の河川水と湖 面への直接降雨によってなされ, 年総流入量はほぼ 湖容量に相当する. 一方, 湖内への塩分の供給は, 湖水位と外海水位の逆転時に高瀬川河口より遡上流 入する外海水によって間欠的になされているゔ. の塩水流入と低塩分表層水の流出がほぼバランスし， 


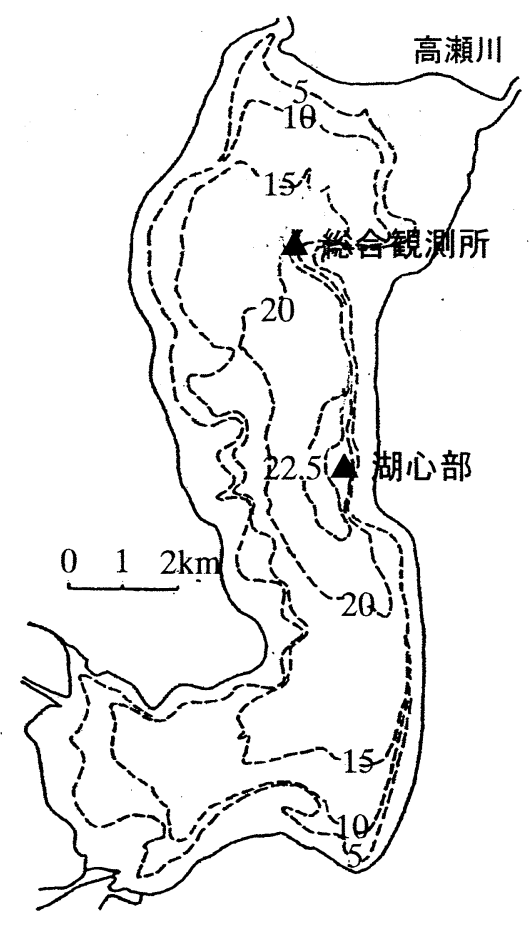

図-1 小川原湖
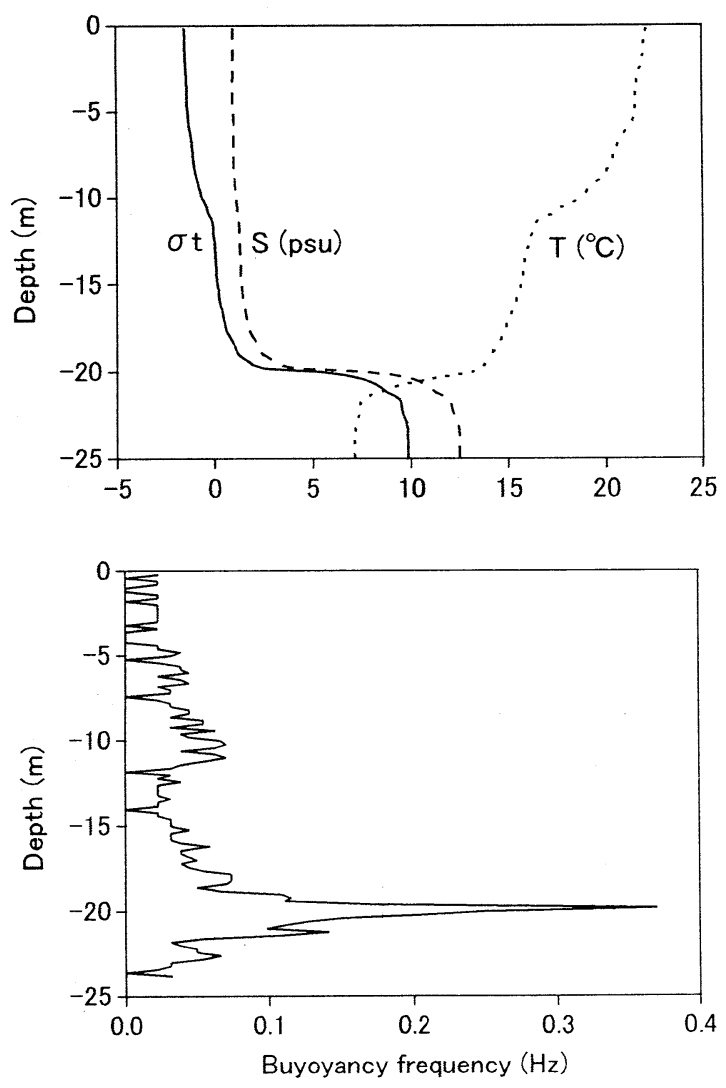

図-3 成層構造とバイサラ振動数の鈗直分布

近年, 小川原湖では水深18～21m以深の底層部に一年 を通して約12psu（海水の約1/3）の嫶水が存任し， 安定した塩分循環を保っている。水温の成層化は 5

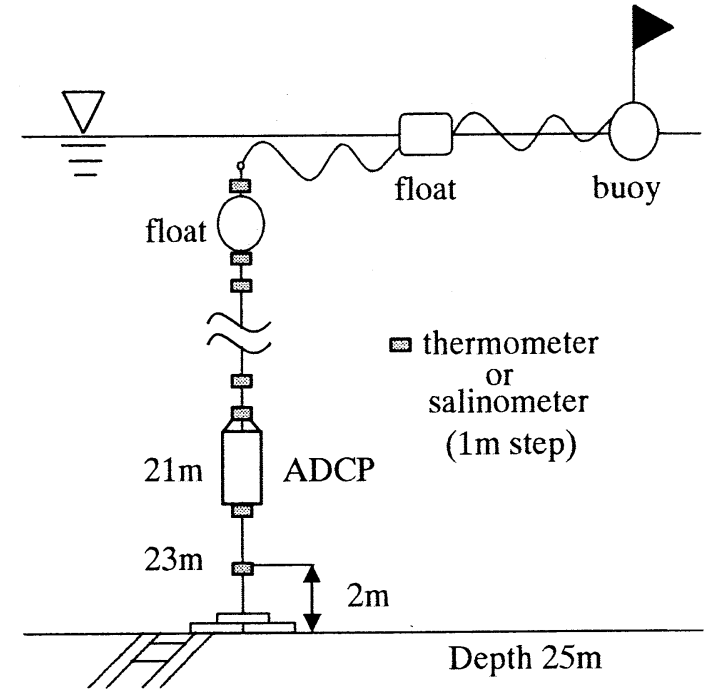

図-2 計測機器設置状況（最深部, 全水深 $25 \mathrm{~m}$ )

月に始まり, 観測を実施した 8 月に最も発達する. 気温が低下する 9 月から混合層厚が增し，10月には 水温成層は破壊され, 塩淡二成層となり循環期を迎 える. 一年を通して, 表層塩分濃度は $1 \sim 2 \mathrm{psu}$ の值 を示している6.

小川原湖には, 多様な生物相が生息し, 生物量も 高い水準にある. これは, 淡水域から高塩分域まで 広範囲に及ぶ塩分環境によるところが大きい。この 塩分環境は, 水温成層状況と大きく関係し, その変 動は生態系に大きな影響を及ぼしている，また，魚 介類の生育に影響を及ぼす溶存酸素も, 水温成層と 大きく関わり, 平成 6 年の猛暑渇水年には, 小川原 湖においてシジミ貝の大量死が報告されている.

これまで, 小川原湖の巨視的な塩分循環過程に関 する研究 $\left.{ }^{5}, 6\right), 7$ はなされてきたものの, 湖水流動と成 層破壊機構の実態に関する十分な調査・解析は未だ なされていないのが現状である.

\section{3. 現地観測}

1998年7月28日〜8月20日にわたり，図-1に示す小 川原湖の湖心部 (最深部, 全水深 $25 \mathrm{~m})$ にADCP (1200kH Z）を設置し，鈶直流速分布を10分間隔で計測した. 使用したADCPの最大計測レンジが $20 \mathrm{~m}$ 以下であるこ とを考虑し, 本体を水深約 $21 \mathrm{~m}$ に設置し, 表層から水 深約 $20 \mathrm{~m}$ までの流速計測を行った. 同時に, 同地点に おいて $1 \mathrm{~m}$ 間陪に水温計もしくは塩分計を設置し, 成 層構造の変動も併せて10分間郘で計測した．機器の 設犆状沉は，図-2に示すとおりである。また，観测 期間にSTDを朋いた水温・嫶分の鉛直分布観测も实施 した。解析に必要な気商デー夕等は, 湖北に位监す る湖内総命観測所で定時観测されているものを利用 した。 
a) 風速·風向

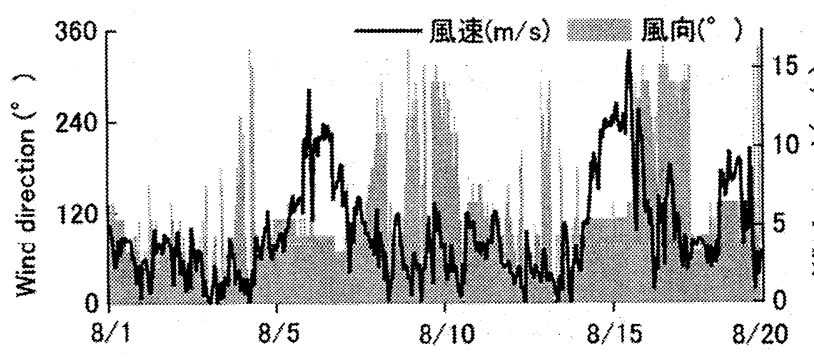

b) 水温

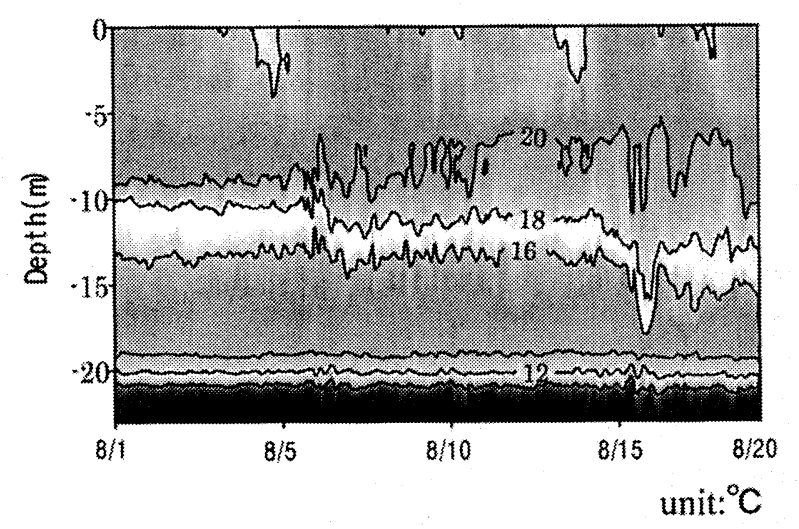

c) 流速

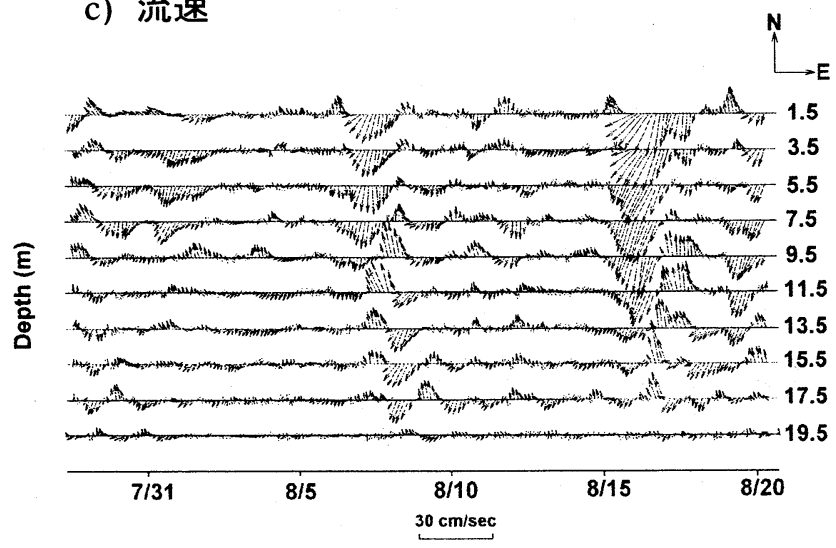

図-4 水温·流速変動

\section{4. 観測結果および解析}

\section{（1）密度の鉛直構造}

観測開始時の $7 / 28$ に最深部でSTDを用いて計測さ れた水温塩分構造とバイサラ振動数 $N$

$$
N^{2}=-g / \rho \times d \rho / d z
$$

の鉛直分布を図-3に示す. 水深 $10 \mathrm{~m}$ 付近には水温躍層 が存在し, さらに約 $20 \mathrm{~m}$ 以梁の底層部には約 $12 \mathrm{psu}$ の 塩水が貯留され強い塩淡境界面を形成していること がわかる. 密度構造は, 概小上層の水温二成層と下 層塩水層の三層構造をなしている.

（2）水温変動と流速変動

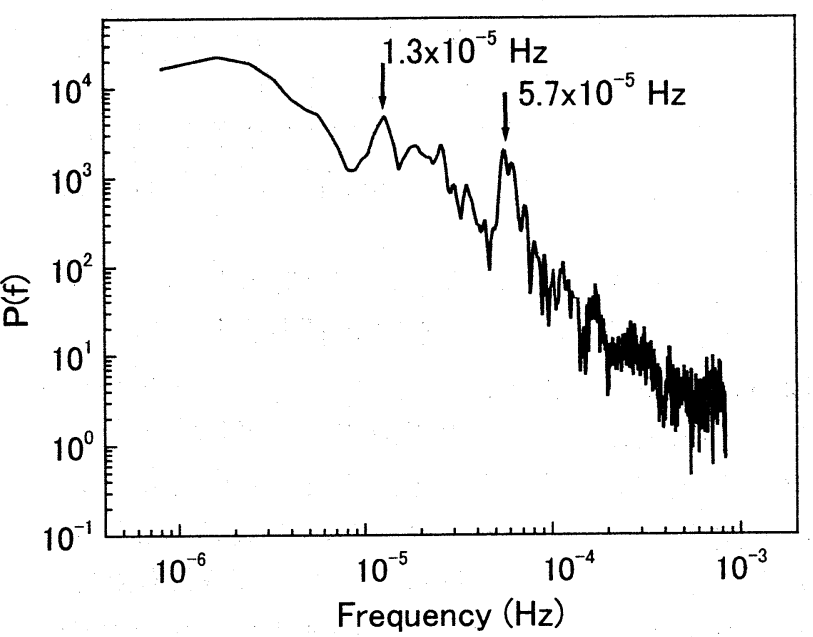

図-5 水温変動のパワースペクトル (水深 $10 \mathrm{~m})$

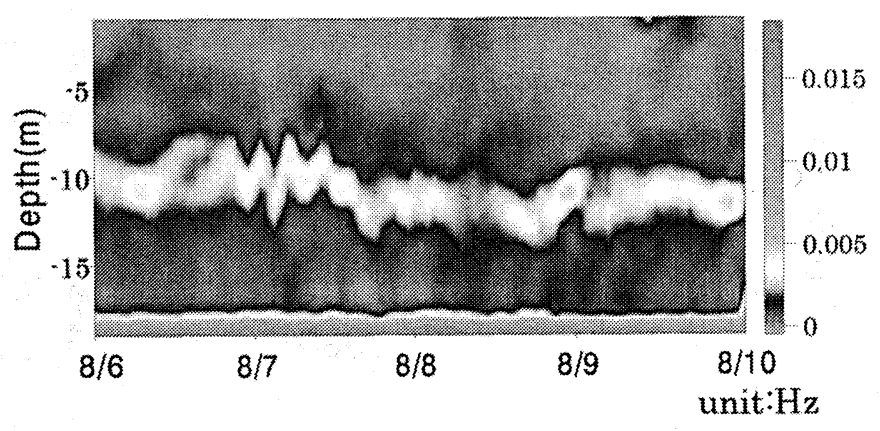

図-6 バイサラ振動数の時空間変化

図-4は, 水深 $1 \mathrm{~m}$ 間隔で連続観測された水温と流速 デー夕を基に描いた水温等值線と水平流速（北流成 分と東流成分の合成ベクトル）の変動を示したもの である. ただし，デー夕には1時間の移動平均を施し ている.また，図には湖内総合観測所で計測された 風向・風速も併せて示している.

$20 \mathrm{~m}$ 付近の強い水温躍層は塩淡境界によるもので, 成層強度には塩分濃度が支配的となっている. $8 / 7$ 前 後と $8 / 15$ 前後の $10 \mathrm{~m} / \mathrm{s}$ を超える強い南東風に連動し て, 水温等值線が大きく変動している. 特に8/15に は水深 $10 \mathrm{~m}$ 付近の水温躍層が急激に低下し, 成層強度 の差異により水温躍層の変動規模にも相違が見られ る. 風停止後も, 躍層部では風によって誘起された 内部静振や内部波が長期間継続して存在しているこ とがわかる. 水温躍層の急変現象後に躍層降下が回 復しなかったことから, 風による大きな混合が生じ たこともわかる.

ちなみに, 成層湖沼の界面変動と混合形態のパラ メタであるWedderburn数 ${ }^{8)}$

$$
W=R_{i *} \times 2 h_{1} / L
$$

$\left(h_{1}\right.$ : 上層厚, $L:$ 湖長, $R_{i *}$ : 水面の摩擦速度と上層 厚を代表スケールとしたRichardson数)を用いて, 水 温躍層（水深 $10 \mathrm{~m}$ ) の湧昇限界を $W=1$ の条件から求 
めてみると, 小川原湖の主軸である南北方向 $(12 \mathrm{~km})$ に対しては, 風速約 $12 \mathrm{~m} / \mathrm{s}$ の值を得た. 最大風速 $16 \mathrm{~m} /$ sが観測された $8 / 15$ の躍層の大きな変動は, 風向を考 慮すればほぼ湧昇限界にあったことが予想され, 風 速の減衰にともない大きな内部静振が生じたものと 考えられる.

図-5は，水深 $10 \mathrm{~m}$ で計測された水温変動のスペク トルである. $1.3 \times 10^{-5} \mathrm{~Hz}$ (周期 21 時間) と5. $7 \times 10^{-5} \mathrm{H}$ Z (周期 4.9 時間)に卓越したスペクトルピークがみら れる. 小川原湖の形状と観測期間の密度構造より水 温躍層の静振周期を算定したところ 26 時間と得られ， 低周波側のスペクトルピークはこの 1 次の内部静振 に対応するものと考えられる. 一方, 高周波側のピ 一クの周期は 4.9 時間と短く, 横静振または伝播性の 内部ケルビン波に対応するものと考えられるが, 1

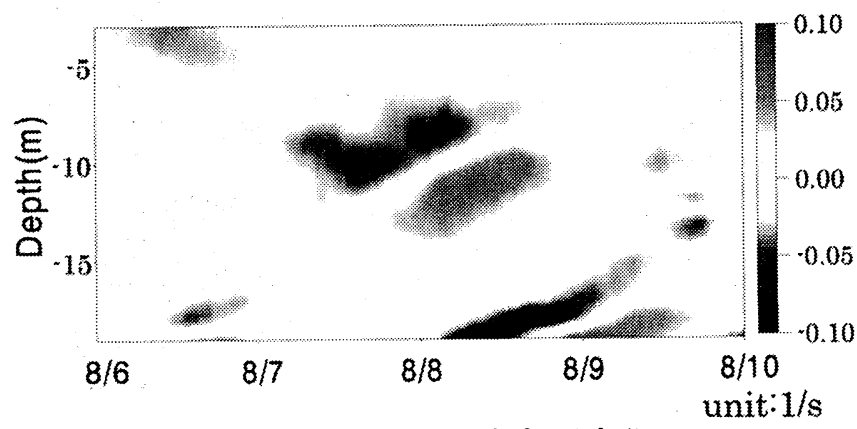

図-7 シアーの時空間変化
地点の観測のためその特定には至っていない．

図-4c)に示した流速変動にもこの 1 次モードの静 振の発生による卓越した変動が明瞭にとらえられて おり, 流動構造は水温成層の影響を受けて水深方向 に位相変化し，波動場の特性を有している. その結 果, 例えば8/8には水深約 $10 \mathrm{~m}$ の躍層付近では上下で 反転した流動がみられ，大きなシアーが生じている ことがわかる. 後述のように, このシアーの生成が 混合現象に支配的な役割を果たしているものと考え られる. また, 風速約 $10 \mathrm{~m} / \mathrm{s}$ に対し表層部混合層では $20 \mathrm{~cm} / \mathrm{s}$ 近くの流動が生じているとともに, 塩淡境界 面近くの深部においても大きな流動が発生している ことがわかる.この強い流動は, 塩淡境界面をも刺 激し短周期の界面波を発生させていることもわかる.

\section{（3）シアーの時空間構造}

成層強度を表すパラメタとしてバイサラ振動数 $N$ の変動を示したのが図-6である，吹風による混合層 厚の増加と躍層の低下がみられるとともに, 内部波 に応じ周期的変動も現れている.

ADCPによって得られた $1 \mathrm{~m}$ 間隔の流速分布を基に, 流速の鈶直方向勾配の時空間変動を求めたのが図-7 である，吹送流発達段階では，水面における直接的 なせん断により表層でシアーが生じ, 時間の経過と ともに下方にシア一域を拡げている. しかし，風速 が減衰し始めると, 大きな内部変動の発生により躍

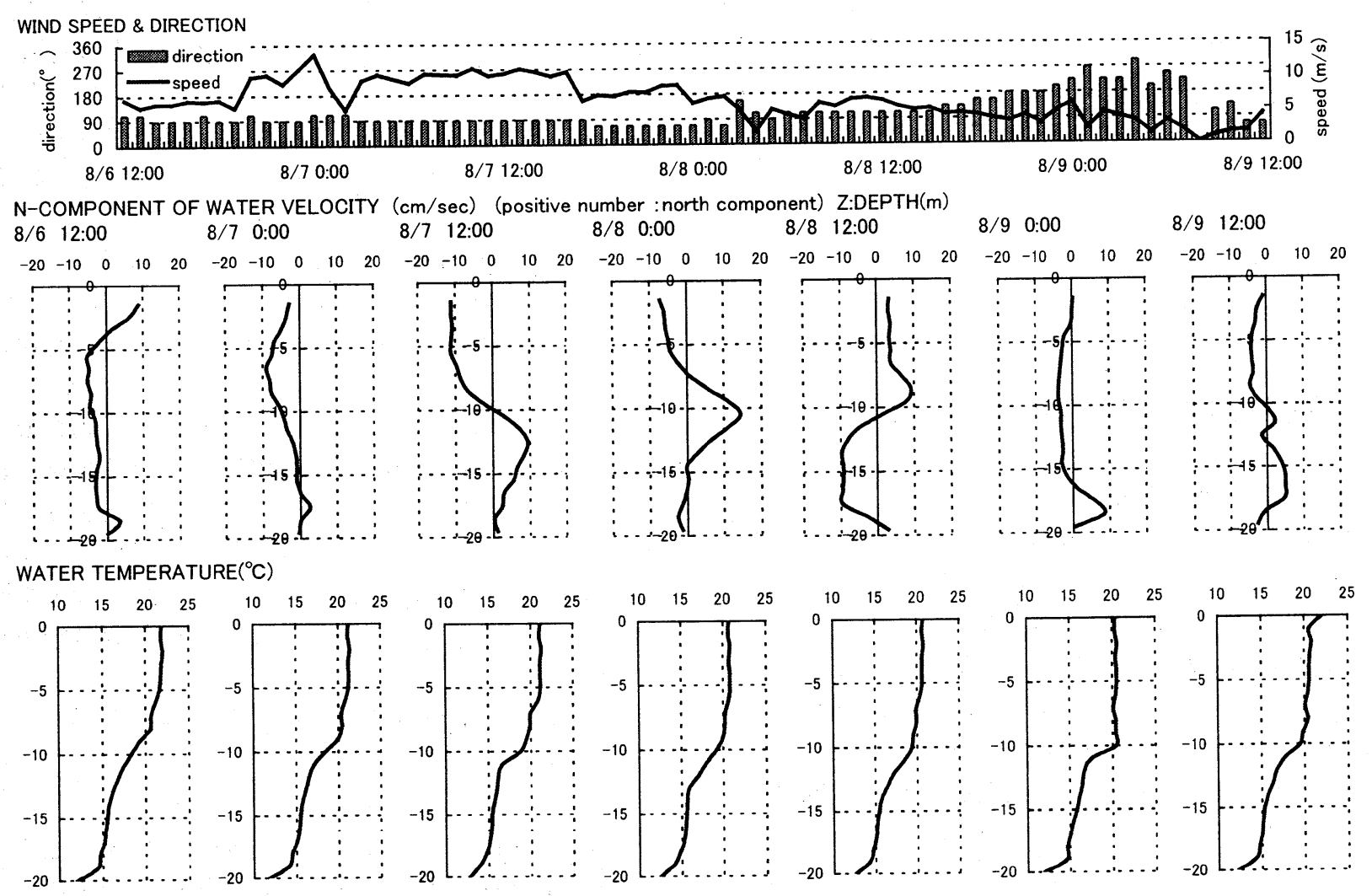

図-8 流速分布と密度分布の経時変化（8/6 8/9） 


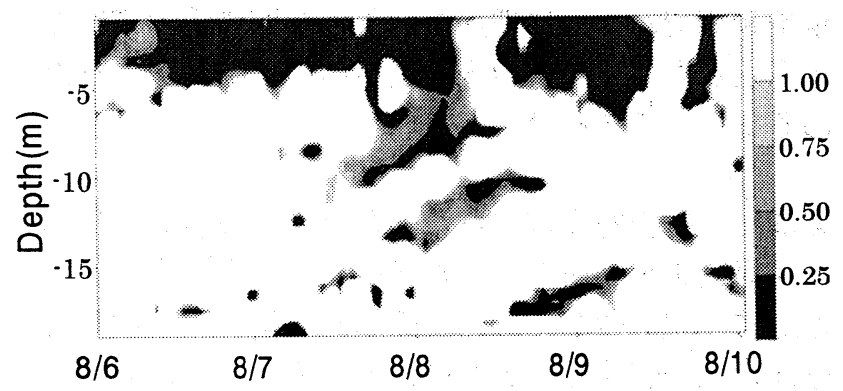

図-9 Richardson数の時空間分布 $(\mathrm{Ri}<1)$

層付近に表層よりも強いシアー域が現れ，表層から のシアーの発達状況とは異なり, 時間の経過ととも に上方にシア一域を拡大している. その後, 塩淡境 界上部にも強いシアー域が出現し，躍層部と同じく 時間の経過に伴い上方にシアー域を拡大しているの がわかる. このシア一域の上方移動は, 成層効果に よる内部波動の鉛直方向位相変化に起因するものと 考えられるが，詳細は明らかでない，この期間にお ける一連の流速と水温分布の変化を示したのが図-8 である. 強いシアーの発生と内部波の発生に伴う大 きな流速変動, その結果生じる混合層の発達, さら には塩淡境界面での流動の発生等, その構造の変化 がよくわかる.

\section{（4）不安定性と成層破壊}

内部流動によって引き起こされるせん断不安定の 可能性を定量的に評価するため, 勾配型局所リチャ 一ドソン数 $R_{i}$

$$
R_{i}=N^{2} /(d u / d z)^{2}
$$

の鉛直分布の経時変化を算定した. 図-9には， $R_{i}$ の 時空間変動を図示した. シアーの時空間構造と同様 に不安定性の出現可能領域 $\left(R_{i}<0.25^{9)}\right)$ は, 時間の 経過とともに 3 つに大別できる. 第 1 は吹送流発達 段階における不安定域の出現で，風の発達とこもに 表層から生じる．第 2 は内部静振の発生に伴う不安 定域で, 風の減衰にともない躍層付近で出現する.

第 3 は上層内の内部静振に誘発されて出現する塩淡 境界面直上の領域である. 以上のように, 風による 混合が水表面からの直接的な乱れの供給とシアーの 発生による他，風減衰時に発生した内部波動による 強いシアーが躍層付近の混合に大きく寄与している ことが予想される，さらに，塩淡境界面直上に形成 される不安定域の出現は，3 層構造をなす深大な汽 水性の小川原湖の特性とも言え，塩分輸送に大きな 役割を果たしていると考えられる. 過去の観測結果 をみると, 成層期には水温躍層の下部から塩淡境界 面に至る水深に塩分の漸変層が発達し, 表層への塩

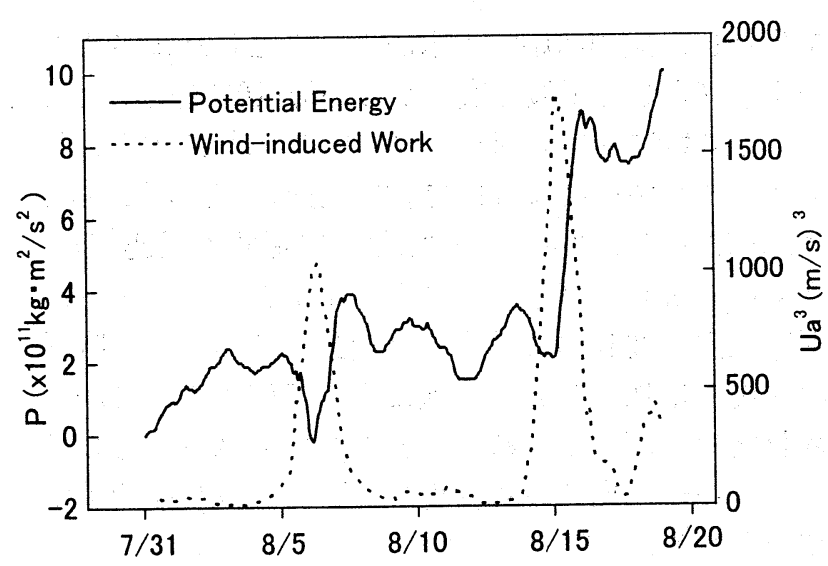

図-10 ポテンシャルエネルギーの変化

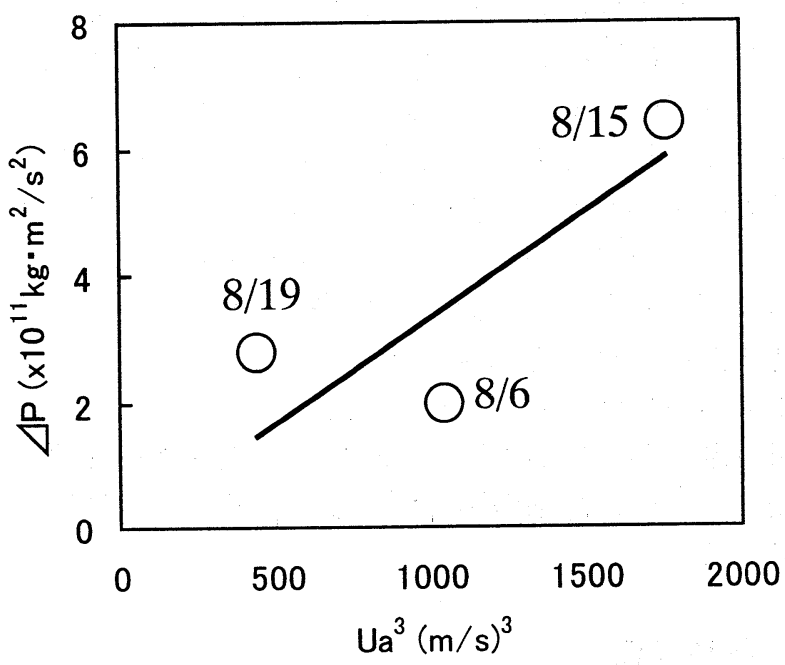

図-11 風速と混合エネルギーの関係

分供給の役割を果たしている. 塩水層からの塩分連 行と漸変層の発達に, 上述の不安定領域の出現が大 きく作用しているものと考えられる．さらに，この 不安定域は時空間的な過程を経て形成されるもので, 風との直接的相関関係は見いだせない. そのため,

これまで行われてきたような風速または表層せん断 力をパラメ夕とした, 連行拡散の定量化と予測手法 の下層塩淡境界への適用は困難と考えられる.

成層破壊の過程をエネルギーの面から評価を行っ てみる. 成層化した湖沼の有するエネルギーは, ポ テンシャルエネルギーや, 流動（循環流）エネルギ 一, 乱れエネルギー等のエネルギーの総和で与えら れる(10).ここでは, 混合現象に着目しポテンシャル エネルギーの増減，つまり混合の有無について解析 を行うことにする．簡単のため熱輸送に関しては考

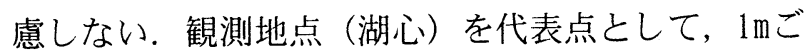

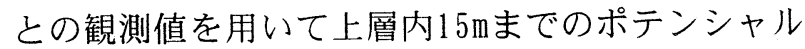
エネルギー 


$$
P=\int \rho g z A(z) d z
$$

を算定し, 観測開始時の水面を基準としたエネルギ 一を基底として増減で表したのが図-10である.ただ し, $A(z)$ は各層の等深面積であり, 得られたポテンシ ヤルエネルギーには1日移動平均を施している. 図に は, 風によるエネルギー供給量に関係する風速 $U a$ の 3 乗值も併せて図示している. ポテンシャルエネル ギーは内部波動の影響を受け変動しているが，吹風 の前後で増加しており，風によって確かに混合がな されたことが見てとれる. また，風の強さに応じて エネルギーの増加量も変化し, 両者には相関関係が 認められる。

図一11は，代表的な吹風時の $U a^{3}$ とポテンシャル エネルギーの増加量 $\Delta P$ の関係を示したものである. $P$ 変動には波動成分も含まれるため, 混合による エネルギーの変化の分離抽出は困難である. そのた め, ここでは巨視的な混合特性を捉えるために近似 的に, 吹風直前の $P$ と吹風後の最大の $P$ を用いて $\triangle P$ を算定した。 また，風速についても各イベント の最大風速をもって代表させている．結果をみると 得られたデー夕は少ないが、おおよそ両者には線形 の関係が認められる.もしも線形関係が成立すれば, 風速または水面の摩擦速度を速度スケールとして - 1 乗の連行則が成り立っていることを示すもので, 小川原湖においても表層に形成される混合層の発達 予測に, この連行則の適用が可能であることを意味 している。

\section{5. おわりに}

小川原湖での観測デー夕を基に, 夏季における湖 水の流動現象の解析を行い, その実態把握と変動特 性の解析を行った，成層化した湖では表層から供給 される乱れに起因した混合と，循環流によって生じ るシアーに起因した混合が支配的とされている。し かし今回の観測により，風の減衰期や停止後にも内 部で大きなシアーが形成され，成層破壊に至るに十 分な不安定性が生じることがわかった，さらに，小 川原湖の塩分環境を決定する底層塩水の連行には, 風停止後に塩淡境界面值上に形成される強いシアー が大きく関わっていることも示唆され，この現象を
取り込んだ新たなモデル化が必要と考えられる。今 後, 数值実験による再現計算との比較検討を行い, 現地観測では十分に把握できない空間構造の解明を 行うとともに, 混合現象の精度の高いモデル化を進 めるつもりである.

謝辞 : 本研究を実施するにあたり, 建設省高瀬川総 合開発工事事務所から水理デー夕の御提供を頂くと ともに，現地観測において御高配を頂いた。記して 感謝の意を表するとともに, 本研究の一部は文部省 科学研究助成の補助を受けて実施できたことを付記 する.

\section{参考文献}

1）道奥康治・神田徹・石川勝久：貯水池での水温計測に 基づく内部波・自然対流の抽出，水工学論文集，vol.43， pp. 1049-1054, 1999.

2）大久保賢治 -長井重威・大林史典 : 湖の多重抎散対流 場における正逆水温躍層の形成とその界面現象, 水工学論 文集, vol.41, pp. 463-468, 1997.

3）石川忠晴・田中昌宏 : DIM型連行現象に関する理論的考 察, 土木学会論文集, No.416/II-13, pp. 99-108, 1990. 4）池永均 他：網走湖の塩水化の機構と塩淡二成層の長 期変動特性に関する研究, 土木学会論文集, No. 600/ II -44, pp. 85-104, 1998.

5）石川忠晴 : 小川原湖に侵入する塩分の計算モデルの検 討, 水工学論文集, vol.35, pp.191-196, 1991.

6）藤原広和 他：小川原湖の塩分鈆直分布と河口水位变 動に関する現地観測，海岸工学論文集，v01.46， 1999.

7）長尾正之・石川忠晴・長島伸介：小川原湖に発生する 傾斜プルームの現地観測と連行係数の推算, 土木学会論文 集, No. 579/II-41，pp. 105-114， 1997.

8) Spigel, R.H. and J .Imberger : The classificatio $n$ of mixed-layer dynamics in lakes of small to medi um size, J.Phys.0ceanogr., Vol.10, pp.1104-1121, 1 980.

9) Simpson, J.H. and J.R. Hunter (1974): Nature, Vol. 250, pp. 404-406, August 2.

10) Stevens, C. and J. Imberger: Initial response of a stratified lake to a surface shear stress, J. Flu id Mech., Vol.79, pp.39-66, 1996.

(2000.10.2受付) 